\title{
MARY AND FÁTIMA: A MODEST C-INDUCTIVE ARGUMENT FOR CATHOLICISM
}

\author{
Tyler Dalton McNabb E JOSEPH E. Blado*
}

University of St. Joseph, Macau | Houston Baptist University

\begin{abstract}
C-Inductive arguments are arguments that increase the probability of a hypothesis. In this paper, we offer a C-Inductive argument for the Roman Catholic hypothesis. We specifically argue that one would expect the Miracle of Fátima on Roman Catholicism more so than on alternative hypotheses. Since our argument draws on confirmation theory, we first give a primer for how confirmation theory works. We then, provide the historical facts surrounding the Miracle of Fátima. We offer up two competing naturalistic explanations that attempt to explain the historical facts, but then, argue that a supernatural explanation is superior. Having established that something miraculous likely occurred at Fátima, we move to argue for the overall thesis of the paper. Finally, we engage several objections to our argument.
\end{abstract}

KEYWORDS: Fátima, Miracle of the Sun, Swinburne, Roman Catholicism

C-Inductive arguments are arguments that increase the probability of a hypothesis. This can be contrasted with what is called a P-Inductive argument. A P-inductive argument is an argument that shows the overall probability of a hypothesis to be more probable than not (Swinburne 2014: 6). In this paper, we put forth a C-inductive argument for the truth of the Catholic hypothesis $(\mathrm{CH})$. Roughly, we take $\mathrm{CH}$ to be the hypothesis that the core creedal beliefs found within the Catholic Tradition are true [This can best be summarized in the Catechism of the Catholic Church]. Specifically, we argue that we would expect the Miracle of Fátima on $C H$, but, we wouldn't expect it as much on $\sim C H$. In order to establish this thesis, we first discuss the basics of confirmation theory. Second, we give the historical context of the Miracle of Fátima. Third, we briefly survey and then reject two possible non-supernatural explanations of the apparent miracle. Doing this will help make plausible that the Miracle of Fátima is actual evidence that a hypothe-

* TYlER DALTON McNABB (PhD 2016, University of Glasgow) is Assistant Professor of philosophy at the University of Saint Joseph, Macau, and formerly postdoctoral fellow at the University of Macau. Email: Tylerdaltonmcnabb@gmail.com.

JOSEPH E. BLADO (BA 2019, Houston Baptist University) is a student at Houston Baptist University. Email: BladoJE@Hbu.edu. 
sis needs to predict. Fourth, we give the details as to why we should expect the Miracle of Fátima more on $\mathrm{CH}$ than $\sim \mathrm{CH}$. Finally, we argue that miracles that occur in Protestant contexts, generally don't carry the same evidential weight for a Protestant hypothesis as the Miracle of Fátima carries for $\mathrm{CH}$.

\section{Confirmation Theory and Background Knowledge}

Roughly, one assesses the probability of a hypothesis in light of the background knowledge assumed, and the evidence observed. The theorem (Bayes' theorem) goes as follows:

$$
P(h / e \xi k)=\frac{P(e / h \xi k) P(h / k)}{P(e / k)}
$$

$H$ stands for the hypothesis in question, $e$ the evidence, and $k$ the background knowledge assumed-which is to say the background assumptions about what's true relevant to the world we live in.

Now, when assessing the probability of a given hypothesis, the theorem considers two main elements: (1) the explanatory power of the hypothesis, and (2) the intrinsic probability of the hypothesis. With respect to (1), this element asks whether the hypothesis in question predicts the data. Here, $P(e / h \xi k)$ is the probability of observing the evidence on a certain hypothesis and background knowledge. With respect to (2), or more formally $P(h / k)$, one considers whether the hypothesis fits in $k$, and if $h$ is relatively simple.

A good C-Inductive argument is an argument from an individual event or evidence $(e)$ to the hypothesis $(h)$ if and only if (iff) $P(e / h \xi k)>P(e / k)$, and this will be the case iff $P(e / h \xi k)>P(e / \sim h \xi k)$ (Swinburne 2014: 110). Put slightly differently, if one should expect $a$ priori the observed $e$ on $h$ (and $k$ ) rather than on $\sim h$ (and $k$ ), then this should be a good C-inductive argument for $h$. C-Inductive arguments increase the probability of the hypothesis being true, but they do not demonstrate overall probability of $h$ being true over $\sim h$. In order to make such an assessment, one would need to take into account all of the relevant data, as well as the intrinsic probability of $h$. Since this task would be beyond the scope of this paper, we will focus on the event at hand-namely the Miracle of Fátima [Unless explicitly specified otherwise, by Miracle of Fátima, we want to include, not only, the Miracle of the Sun, but also those Marian Apparitions that predicted and preceded the event].

Thus, more specifically, where $h$ is the hypothesis of Roman Catholicism being true $(\mathrm{CH}), e$ is the event that the Miracle of Fátima occurred, and $k$ is the background knowledge that Nicene Creed Christianity is true, and, that the Scriptures teach that Mary is the Queen of Heaven, the Ark of the Covenant, and the new Eve, we argue that we should expect the occurrence of $e$ 
more so on $C H$ rather than on $\sim C H$. In Bayesian terminology, we argue that $P(e / h \xi k)>P(e / \sim h \xi k)$. If successful, we shall have a successful CInductive argument that increases the probability of Roman Catholicism being true.

The most controversial assumptions that we make all relate to how Mary is portrayed in the Christian Scriptures [For a systematic theology on Mary in the Christian Scriptures, readers might be interested in Levering 2015]. With respect to Mary being the Queen of Heaven, we find persuasive Brant Pitre's argument that since the Queen in the Davidic Kingdom is always the King's mother, we should assume that since Jesus is a Davidic King, that Jesus' mother is likewise the Queen (Pitre 2018: 74; Hahn 2006). In the Hebrew Bible, the Queen mother would reign with the King, share the King's power as she sits at his right side (1 Kings 2:20, Psalms 45:6-9), and could act as an intercessor (1 Kings 2:13-14, 17-18) (Pitre 2018: 74-79).

With respect to showing that Mary is the New Ark of the Covenant, Pitre contrasts 2 Samuel 6:2-16 with Luke 1:35-56. Both David (2 Samuel 6:2) and Mary (Luke 1:39) go into the hill country of Judea. David admits to his unworthiness when he encounters the Ark of the Covenant (2 Samuel 6:9) just as Elizabeth conveys her unworthiness when she encounters Mary (Luke 1:43). Just as David leaps for joy when he encounters the Ark (2 Samuel 6:15-16), so John in the womb leaps for joy when he encounters Mary (Luke 1:41-42). And finally, the Ark remains in the hill country for three months (2 Samuel 6:11) just as Mary remains in the hill country for three months (Luke 1:56) (Pitre 2018: 58).

Finally, as Pitre points out, Mary is portrayed as the new Eve in the Gospel of John. Both Genesis and John start off with the phrase, 'In the beginning'. Both books also follow this phrase with darkness and light imagery. In Genesis, we see the man and the woman together in a Garden on the 7 th Day. In John, the man is with the 'woman' at a wedding feast on the 7th day. How do we get that the wedding feast is taken place on the 7 th day? In chapter one of John, we see the phrase 'The next day' repeated three times. Assuming that there was a day that took place before 'the next day', we can count a total of four days. We then see John move to discussing 'The third day' (John 2:1) in the context of the wedding at Cana. Pitre states, 'Notice here that the way scholars arrive at seven days is by interpreting John's references sequentially and adding the first four days to the 'third day' (4 Days +3 Days $=7$ Days) (Pitre 2018: 27). Jesus then at the wedding in Cana calls his mother, 'woman' which of course echoes back to what Eve is called in chapter one of Genesis. The allusion and typology seem clear [As Pitre notes, both Catholic and Protestant commentators recognize that John is referring back to Genesis with respect to the 7-day typology. As he suggests, see Bauckham 2015: 132-35; Martin and Wright IV 2015: 42-61; McHugh 
2014: 176-177]. Perhaps this in part is why Mary is recognized as the new Eve by some of the Church Fathers. Having discussed what we have taken into our background knowledge, we now move to make a case for $e$.

\section{The Miracle of Fátima}

In the early 1900s, Christianity in Portugal was predicted to become extinct. Seminaries were closing and very few people were joining the priesthood [See Jaki's discussion of Catholicism pre-1917 in Jaki 1999]. Portugal, from a Catholic in Portugal's point of view, needed a major revival. The apparitions of Mary to the children and the miracle that occurred at Fátima, helped meet this need.

Broken down, there were a total of nine appearances to the three shepherd children involved in the events at Fátima-the first three of which were appearances of the guardian angel of Portugal, and the latter six of which were of the Virgin Mary. During the three appearances of the guardian angel, the angel encouraged the children to fervently pray to the hearts of Jesus and Mary as the angels offered them the Eucharist. The angel proclaimed to them, 'take and drink of the Body and Blood of Jesus Christ, horribly outraged by ungrateful men. Make reparation for their crimes and console your God' (Varghese 2011: 109).

Soon afterwards, on May 13th, the Virgin Mary appears to the children for the first time. Mary tells them that she comes from Heaven, and that she wants to continue to meet them every thirteenth of each month for six months. During the following month, June 13th, Mary appears again and openly proclaims that one of the shepherd children, Lucia, will soon be alone (the others will die) and that she would have to spread a devotion to her Immaculate Heart (Varghese 2011: 109-111). During the third appearance, word of the Marian appearances had spread, and a some two to three thousand people gathered at the site where Mary would appear to the children. When Mary appears, she shows the children a vision of hell and calls them once again to establish a devotion to the Immaculate Heart of Mary.

The fourth appearance (August the 13th) does not go as planned as the children's civil administrator intervenes and kidnaps the children until August 15th (Varghese 2011: 110). One by one the civil administrator takes the children into a room and threatens to kill them unless they share a secret which the children claimed the Virgin entrusted them with (Bennet 2012). All three children, however, consistently keep to their testimony that the Virgin Mary had been appearing to them, thus, seemingly vindicating the sincerity of their beliefs. Mary again appears to the children after the incident on the 19th of that month and encourages them again to do penance for the sins of the world (Varghese 2011: 111). 
The fifth appearance occurs on September the 13th, where Mary proclaims the importance of reciting the Rosary. The subsequent month, it rained all day prior to the appearance and up until the predicted appearance at noon. Around noon, the raining stopped, and the sun came out (Bennett 2012). Here, most of those who were at Fátima at the time (roughly, 50,000-100,000) saw something fantastic. The standard story is that the crowd, without pain, looked upon the sun (or something that looked like the sun) and saw the sun turn multiple colors and dance. It was widely reported that the sun ended up moving towards the crowd as if it were about to crash, and then right before it appeared like it was going to hit the earth, the sun returned to normal (Bennett 2012). There is some disagreement about what exactly happened. For example, some of the witnesses debated whether the sun moved, and some claimed that they did not see anything at all (Jaki 1999: 170-171; Haffert 1988). Regardless, the vast majority seemed to agree that something unexplainable happened. It is also widely reported that while the crowds were still staring into the sky, their clothes became completely dry within minutes. Shocked by all of this, the common belief in Fátima was that a miracle had occurred. What followed was a robust Catholic revival throughout Portugal.

\section{Alternative Explanations}

We now move to engage the two most plausible naturalistic theories as to what happened at Fátima. First, there is what we call the Solar Retina theory. Roughly the theory is that the people of Fátima experienced phenomena that can occur when one's retina gets damaged by the sun. Stanley Jaki quotes Stöckl in describing how this damage leads to seeing the sun change colors and dance:

When the sun is high in the sky it is dangerous to look at it even for a few seconds. When the sun is not so high, namely, when veils of clouds, or humidity and dust dominate more and more in the atmosphere and dampen the sunlight, one can for several minutes look at the sun, without damaging the eye. The following subjective effects may arise (I myself made that experiment several times): After almost a minute (the time varies according to the condition of the atmosphere and the momentary condition of the eyes) one thinks to see a dark blue disk in front of the sun (this is already a sign of the highly excited state of the retina). According to my experience... the dark blue disk is somewhat smaller than the solar disk, so that the edge of that disk stands out as a ring beyond that dark blue disk. Then one has right away the impression that the solar disk rotates with great speed in one or the other direction (Jaki 1999: 303).

Monique Hope-Ross, Stephen Travers, and David Mooney studied four persons who, on their own initiative, decided to look at the sun to see if they could see Mary or perhaps repeat what was seen at Fátima (Hope-Ross, 
Travers, Mooney 1988: 931-934). Only one of the four persons saw the sun turn different colors and dance around; and this was only seen after several attempts were made. All four individuals were left with permanent eye damage. In addition to this, Auguste Meesen, a physicist at Catholic University of Louvain, tried this experiment. While he did not see the sun move in any way, he did see the sun change different colors (Meesen 2003: 5).

According to Ross, Travers, and Mooney, 'the phenomena described is known as solar retinopathy and it is due to a combination of thermal and photochemical injury... It is thought that solar retinopathy is caused by the photochemical effects of the short wavelengths in the visible spectrum at 400-500 nm, with some thermal enhancement from longer wavelengths in the infrared' (Hope-Ross, Travers, Mooney 1998: 933). Could this be what happened to those observers at Fátima?

Perhaps. This theory however, fails to explain several facts surrounding the events at Fátima. First, it fails to explain how the observers' clothes quickly became dry after the events had unfolded. Second, there appear to be reported witnesses who were not looking up toward the sun for a significant period of time, but nonetheless, saw the sun change colors and dance [This is what seems to be implied in Mrs. da Silva's report of her two employees, Albano Barro's report, and Godinho's report in Haffert 1998]. You wouldn't expect to find such witnesses on the hypothesis that the phenomena were merely produced from eye-damage that results from prolonged observation of the sun. Third, this theory doesn't explain why the clear majority of observers were able to see the phenomena when it's common to look at the sun and not observe such an event. And fourth, it doesn't explain why the children of Fátima sincerely believed that they were coming into contact with Mary. It seems as if one would have to postulate an additional hallucination theory to make sense of their sincerity. Given all this, the Sola Retina Theory doesn't seem to hold up well in its ability to explain the facts.

We think the Meteorological Theory has more going for it. Jaki summarizes how irregularities in the atmosphere could be what was behind Fátima:

The dashing of the image of the sun three times towards the earth may have been caused by a sudden temperature inversion. The latter can be surmised in the oppressive heat, registered by quite a few eyewitnesses, a condition certainly noteworthy in a day that was unusually cold a few hours earlier. The moving to right and left of the image of the sun, as produced by a lens of air full of ice crystals, could be due to turbulence often present in a fast moving air. The combination of shear and temperature inversion could have propelled the lens of air along a curved path, such as an ellipse, on which still smaller circular turbulences could be superimposed. A shift in the position of ice-crystals in that lens of air 
could conceivably change the kind of refraction they produce in the air immediately surrounding them. This in turn can issue in the kind of phenomenon which appeared to the eyewitnesses as a firewheel projecting shafts of light of different color which in turn were reflected on those on the ground (Jaki 1999: 348-349).

On this theory, Jaki thinks the temperature inversion explains why the clothes dried up so quickly. This theory would also explain how there were witnesses who weren't looking up toward the sun for a significant period, but nonetheless, saw the image of sun change colors and dance. This of course is because there would have been real phenomena occurring in the sky. Third, it explains why most observers were able to see the same phenomena, when it's common to look at the sun and not observe the phenomena at Fátima.

However, the theory isn't without its problems. For example, a mere meteorological explanation does not explain why the children of Fátima sincerely believed that they were seeing Mary, and it still does not explain how the children were able to predict when the meteorological happening would occur. Of course, one would not have these problems if Mary really did reveal herself to the children, and if God guided the meteorological happening to coincide with the children's predictions. Following Jaki, we endorse a Meteorological Theory in conjunction with the theory that God was behind the timing of the meteorological event and the Marian apparitions.

What about those who claimed to have seen nothing special occur? We don't have access to judge why it is the case that some claimed to have not seen anything or why some saw the sun change colors but not move. We agree that this is a weakness in the theory proposed. However, as we have argued for, the alternatives seem to explain far less. Regardless of the theory one takes, it seems likely that there was something in the environment that either increased the likelihood of most members in the crowd seeing the phenomena discussed from retina damage, or, increased the likelihood of seeing an irregular meteorological event. On a minimalist view, the Miracle of Fátima is found in the children's ability to predict that some unusual event would occur at the exact place and time. We will now assume the Marian miracle of Fátima $e$ occurred, and turn to the question of whether we should expect $e$ on $C H$ rather than on $\sim C H$.

\section{$\mathrm{CH}$ and Its Predictive Powers}

Recall now the variables previously established, where $e$ is the event that the Marian miracle of Fátima occurred, $\mathrm{CH}$ that Roman Catholicism is true, and $k$ the background knowledge that Nicene Creed Christianity is true in conjunction with the theses that Mary is the queen of heaven and earth, the new ark of the covenant, and the new Eve. Given these variables, should we 
expect that the Miracle of Fátima occurred on $C H$ rather than on $\sim C H$ ? It seems as though we should for two reasons.

First, given $e$, the content of the Marian message (and the angel's) possesses elements unique to the Roman Catholic tradition. These elements include: (1) the consecration to the Immaculate heart of Mary and (2) praying the rosary. With respect to (1), the consecration to the Immaculate Heart of Mary is seen as a specific dedication to the intercession of Mary where one attaches oneself to Jesus more fully through Mary's intercessory prayer. Although this works nicely with the Marian theses on $k$, nevertheless this particular form of dedication to Marian intercession has been uniquely observed by the Roman Catholic tradition for many centuries. With respect to praying the rosary, the rosary consists of a set of prayers that is uniquely Roman Catholic in that it has been both said in the Roman Catholic tradition for ages, and, it conveys what would become the uniquely defined Roman Catholic dogma of the Assumption of Mary.

Second, we should expect that if a figure who represents a specific Christian tradition appears, then it would give credence to the truth of that tradition (assuming the figure does not denounce said tradition). For instance, if Martin Luther appeared with a message from God, then many would consider this to be evidence that the Protestant tradition is correct over the Roman Catholic tradition. Or if John Calvin showed up with a message from God, then this would serve as evidence that the Reformed Protestant tradition is correct over other Protestant traditions (and Roman Catholicism as well). Likewise, the fact that God chose Mary to reveal his message in a Roman Catholic context, that is, a context where heavy Marian devotion is both common and seen as biblical, gives us, evidence that the Roman Catholic tradition is correct.

There are three objections to our thesis, however. First, one could argue for a purely accommodation view in that perhaps God knew that the best way to revive Christianity in Portugal was to have Mary-a significantly Catholic figure-appear to them. Indeed, since Portugal was a significantly Catholic nation prior to the early 1900s, perhaps God utilized Mary to encourage consecration to herself and to pray the rosary in order that Portugal might realize the need for their repentance and Jesus.

Second, one could argue that we should still expect what we state above if the children, who were not sophisticated theologians, utilized their own Catholic upbringing to discuss what Mary had told them. Perhaps Mary said things that fit well with the Catholic tradition because the children were utilizing the religious language that they knew to translate what Mary was telling them.

Third, while the Assumption of Mary is not a defined Dogma within the Orthodox tradition, it nonetheless is affirmed by many within the tradition. 
In fact, Orthodoxy has an extremely high view of Mary. One might then say, that the Miracle of Fátima might also be just as expected on Orthodoxy as it is on Catholicism. This move even seems more plausible when we consider $k$. Mary is after all, a queen intercessor. And, given that she is the new Eve and the Ark of the Covenant, we'd expect her to have success in her intercession. The fruits of the Miracle of Fátima fit very well with all of this.

There seems to be at least one main problem with respect to the first two objections. Amending the hypothesis in one of the two ways suggested, seems to decrease the intrinsic probability by way of postulating more to the hypothesis, namely either (A) God used accommodating language or (B) The children didn't know how to understand Mary, so they translated what she told them with Catholic terms that they understood. These add-ons make the hypothesis less simple. It's far simpler to say that God wasn't using accommodating language to get across His message and that the children passed on what Mary said roughly accurately.

With respect to the third objection, it is important to note that Mary never delivered messages that one should leave the Catholic Church for the Orthodox Church. And, given that the core creedal beliefs of Orthodoxy entail that Roman Catholicism is in grave error, we'd expect Mary to encourage the people of Fátima to abandon their Catholicism for Orthodoxy. Therefore, overall, given the Roman Catholic elements of the Marian message and the fact that God chose a person who is often associated with the Roman Catholic tradition to transmit such a message in a context where she is already venerated, we should expect the Marian Miracle of Fátima more so on $C H$ rather than on $\sim C H$.

\section{Protestant Miracles and the Catholic Hypothesis}

Having now developed the aforementioned C-Inductive argument, we look to engage one last objection. Perhaps, while one agrees that our C-Inductive argument is successful, it nonetheless can be offset or made impotent by competing miracles that happen in anti-Catholic contexts, such as in churches that possess numerous zealous former Catholics. Assuming these miracles to be legitimate, some could see these miracles undercutting-or minimally mitigating - the C-Inductive argument from the Miracle of Fátima $e$, to $C H$ (call the argument from Fátima C-F). Put slightly differently, the event that there are miracles occurring in anti-Roman Catholic Protestant circles $\left(e^{*}\right)$ should be expected on $\sim C H$. In Bayesian terminology then, the $P\left(e^{*} / \sim h \xi^{*} k\right)>P\left(e^{*} / h \xi^{*} k\right)$ —call this argument the Competing Miracles Argument, or CMA.

We think CMA fails as we do not think that we should expect $e^{*}$ any more on $\sim C H$ as we would on $C H$ given $k$. To understand this intuition, consider the following thought experiment. Suppose that a man named 
Jerry has a daughter Sophia. Jerry, being an extremely devout and dedicated Roman Catholic, raises Sophia in the Roman Catholic tradition. As Sophia grows older, Jerry-being the loving and kind father that he ispromises to Sophia that he would bail her out of any financial trouble if she ever fell into such a situation. Sophia, begins to drift away from her father and eventually goes to college, graduates, and begins working a full-time job. As she works, she finds herself dialoguing with her co-workers who are primarily Evangelical Protestants. After much dialogue and discernment, Sophia decides ultimately to leave the Roman Catholic tradition to become a devout Protestant. Not only this, but Sophia's Evangelical Protestant friends influence her so much so, that she becomes extremely anti-Roman Catholic. While her renewed faith somehow sparks a renewed interest in communicating with her father again, all is not well with Sophia. Sophia ends up losing her job after a couple of years working there and cannot seem to make ends meet to pay her monthly payments towards the debt she accrued from her college loans. She turns to her dad Jerry, the devout Roman Catholic, who despite Sophia going against the tradition he raised (and intended) her to be in, nevertheless keeps his promise and pays off her monthly payments. Now, why could this not be the case with the Evangelical Protestant brothers and sisters who call on the name of Jesus? Indeed, Jesus says time and time again that He will grant that which is asked of Him, 'ask and it will be given to you; seek, and you will find; knock and it will be opened to you' (Matthew 7:7), and again He says 'whatever you ask in my name, this I will do, that the Father may be glorified in the Son. If you ask me anything in my name, I will do it' (John 14:13-14). Thus, should we really be surprised that God answers His children when they call on His name? It seems as though we should not, and thus we can equally expect the event $e^{*}$ that miracles occur in anti-Roman Catholic circles just as much on $\mathrm{CH}$ than on $\sim \mathrm{CH}$.

Another modest response to the CMA objection is to say that the nature of the Fátima miracle is such that it distinctly points towards Catholicism, similar to how Jesus' resurrection points to Christianity. Indeed, consider the miracle of the resurrection relative to various miracles outside of Christianity. These miracles include spontaneous healings, monetary or financial support, and perhaps even changes in weather conditions. Although these miracles occur outside of Christianity, the fact that Jesus rose from the dead is a much more potent C-Inductive for Christianity over these various other religions since the nature of the miracle points towards a very specific religious tradition. Similarly, then, since Mary is a very Catholic figure so to speak, her appearance and miracle work-on average-points to the Catholicism over any other tradition. And, as we have argued, there is good 
reason to think that we should expect the Miracle of Fátima on $C H$, and good reason to think we wouldn't expect it as much on $\sim \mathrm{CH}$.

In summary, we have argued that the Miracle of Fátima is indeed evidence for which one could test if a specific hypothesis can predict. We then moved on to argue that $\mathrm{CH}$ predicts the Miracle of Fátima, at least, more so than the alternative hypotheses. Because of this, we argued that there is a good C-Inductive argument for $\mathrm{CH}$. Finally, we argued that most miracles that happen in anti-Catholic environments usually do not carry the same evidential weight as the Miracle of Fátima [We want to thank Jerry Walls and Erik Baldwin for their helpful comments on this paper].

\section{Bibliography}

Bauckham R (2015) Gospel of Glory: Major Themes in Johannine Theology. Grand Rapids, MY: Baker Academic.

Bennett J (2012) When the Sun Danced: Myth, Miracles, and Modernity in Early Twentieth Century Portugal. Charlottesville, VA: University of Virginia Press.

Haffert JM (1988) Meet the Witnesses. Washington, NJ: World Apostolate of Fátima.

Hahn S (2006) Hail Holy Queen. New York, NY: Crown Publishing Group.

Hope-Ross M, Travers S, and Mooney D (1988) Solar retinopathy following religious rituals. British Journal of Ophthalmology 72(*): 931-934.

Jaki S (1999) God and the Sun at Fatima. Royal Oak, MI: Real View Books.

Levering M (2015) Mary's Bodily Assumption. Notre Dame, IN: Notre Dame Press.

Martin F and William MW IV (2015) The Gospel of John. Grand Rapids, MI: Baker Academic.

McHugh JF (2014) John 1-4. International Critical Commentary. London: Bloomsbury T\&T Clark.

Meesen A (2003) Apparitions and Miracles of the Sun. International Forum in Porto, 'Science, Religion, and Conscience', 1-15.

Pitre B (2018) Jesus and the Jewish Roots of Mary: Unveiling the Mother of the Messiah. New York, NY: Crown Rights Publishing.

Swinburne R (2014) The Existence of God. Oxford: Clarendon Press. 